\title{
Enlarged infarct volume and loss of BDNF mRNA induction following brain ischemia in mice lacking FGF-2
}

\author{
Irina Kiprianova ${ }^{\mathrm{a}, *, 1}$, Katharina Schindowski ${ }^{\mathrm{a}, 1}$, Oliver von Bohlen und Halbach ${ }^{\mathrm{a}}$, \\ Sonja Krause ${ }^{\mathrm{a}}$, Rosanna Dono ${ }^{\mathrm{b}}$, Markus Schwaninger ${ }^{\mathrm{a}}$, Klaus Unsicker ${ }^{\mathrm{a}}$ \\ a Interdisciplinary Center for Neurosciences, Departments of Neuroanatomy and Neurology, University of Heidelberg, D-69120 Heidelberg, Germany \\ ${ }^{\mathrm{b}}$ Department of Developmental Biology, University of Utrecht, The Netherlands
}

\begin{abstract}
FGF-2, a potent multifunctional and neurotrophic growth factor, is widely expressed in the brain and upregulated in cerebral ischemia. Previous studies have shown that intraventricularly or systemically administered FGF-2 reduces the size of cerebral infarcts. Whether endogenous FGF-2 is beneficial for the outcome of cerebral ischemia has not been investigated. We have used mice with a null mutation of the $f g f 2$ gene to explore the relevance of endogenous FGF- 2 in brain ischemia. Focal cerebral ischemia was produced by occlusion of the middle cerebral artery (MCAO). We found a $75 \%$ increase in infarct volume in $f g f 2$ knock-out mice versus wild type littermates $(P<0.05)$. This difference in the extent of ischemic damage was observed after $24 \mathrm{~h}$, and correlated with decreased viability in $f g f 2$ mutant mice following MCA occlusion. Increased infarct volume in $f g f 2$ null mice was associated with a loss of induction in hippocampal BDNF and trkB mRNA expression. These findings indicate that signaling through trkB may contribute to ameliorating brain damage following ischemia and that $b d n f$ and $t r k B$ may be target genes of FGF-2. Together, our data provide the first evidence that endogenous FGF-2 is important in coping with ischemic brain damage suggesting $f g f 2$ as one crucial target gene for new therapeutic strategies in brain ischemia.
\end{abstract}

Keywords: Cerebral ischemia; FGF-2 KO; BDNF; trkB; Hippocampus; Parietal cortex

\section{Introduction}

FGF-2 (basic fibroblast growth factor) supports the survival and neurite outgrowth of a wide variety of central and peripheral neurons both in vitro and in vivo (Morrison et al., 1986; Unsicker et al., 1987; Walicke et al., 1986; for review, see Reuss and von Bohlen und Halbach, 2003). Intraventricularly and intravenously administered FGF-2 has been shown to reduce the size of cerebral infarcts (Fisher et al., 1995; Jiang et al., 1996; Sugimori et al., 2001). A multitude of distinct mechanisms has been identified underlying the protective effect of FGF-2 for ischemically and excitotoxically injured neurons. These include downregulation of expression of the NMDA-receptor glu- tamate binding subunit (Mattson et al., 1993), induction of glial cell line-derived neurotrophic factor (GDNF; Lenhard et al., 2002), and increased proliferation and differentiation of neuronal progenitor cells in the dentate gyrus (Yoshimura et al., 2003). While the benefit of exogeneously applied FGF-2 is well documented, it is entirely unclear, whether this pharmacological role of FGF-2 reflects a physiological action of FGF-2 in the ischemic brain.

We have therefore set out to unravel the significance of endogenous FGF-2 in coping with the destructive effects of cerebral ischemia by analyzing mice with a targeted deletion of the $f g f 2$ gene. FGF-2-deficient mice are viable and fertile (Dono et al., 1998; Zhou et al., 1998). They display mild cardiovascular and skeletal alterations, a $20 \%$ reduction in cortical neurons and disturbed cortical layering. Neuronal cell density is normal in the striatum and the hippocampus (Ortega et al., 1998). Astrocytes of $f g f 2$ null mice display an interesting phenotype in that glial fibrillary acidic protein (GFAP), which constitutes intermediate filaments in astrocytes is drastically reduced in gray, but not white matter 
astrocytes of the forebrain (Reuss et al., 2003). Possibly, as a consequence of altered intermediate filament architecture in astroglial cells abutting brain capillaries, mice lacking FGF2 have a leaky blood-brain barrier. Given the crucial role of astroglial cells for neuronal homeostasis, maintenance, and regeneration (see Hatten et al., 1991; Kirchhoff et al., 2001 for reviews), alterations in astroglial functions seen in FGF2-deficient mice might well result in compromised recovery following brain ischemia. This notion is further supported by the established role of FGF-2 in upregulating major neurotrophic and neuroprotective cytokines in cultured and reactive astroglial cells. These include, for example, nerve growth factor (NGF) and GDNF (Suter-Crazzolara and Unsicker, 1996; Yoshida and Gage, 1991).

Brain-derived neurotrophic factor (BDNF) is a potent neurotrophin with both acute roles in synaptic plasticity and morphological and functional recovery in the lesioned nervous system (Gacek et al., 1998; Kafitz et al., 1999; Korte et al., 1995; Saarelainen et al., 2000). It signals through the receptor tyrosine kinase trkB (see Klein, 1994; Malcangio and Lessmann, 2003 for reviews). BDNF, which is upregulated in the adult brain along with its cognate receptor trkB following cerebral ischemia (cf. Lindvall et al., 1992; Merlio et al., 1993), has also been shown to rescue hippocampal neurons after transient forebrain ischemia in rats (Wu and Pardridge, 1999). BDNF given intraventricularly before, and intraparenchymal infusion of BDNF following focal cerebral ischemia significantly reduce infarct volume (Beck et al., 1994; Schäbitz et al., 1997). Interestingly, FGF-2 has been shown to upregulate trkB mRNA (Brumwell et al., 2000) suggesting that BDNF and trkB may respond jointly to FGF-2. We have therefore examined whether regulation of BDNF and trkB is altered in cerebral ischemia depending on the presence or absence, respectively, of FGF-2. We find that mice lacking FGF-2 have a larger infarct volume compared to wild type littermates. Loss of FGF-2 is accompanied by a lack of ischemia-mediated induction of BDNF and trkB mRNA in the hippocampus. This suggests a crucial role of FGF-2 in the lesion-dependent upregulation of these important constituents of the brain's signaling network that ascertains neuron survival.

\section{Materials and methods}

\section{Animals}

$f g f 2-/-$ knock-out mice used for the present study were of the strain generated in a 129Sv:C57BL/6 background by Dono et al. (1998). Animals used for the experiments were mainly derived from heterozygous crosses. Wild type littermates were used as control animals. Mice were examined at 3 to 5 months of age.

The experiments were performed on 76 animals, including MCAO, RT-PCR, and in situ hybridization techniques. The animals with inadequate Laser Doppler exponent (nine mice) and animals that died during surgery (six mice) were excluded from data analysis.

\section{Surgical procedures of the middle cerebral artery occlusion (MCAO)}

The MCAO procedure has been described before (Herrmann et al., 2003; Schneider et al., 1999). Briefly, mice were anaesthetized with $1 \%$ halothane in $33 \% \mathrm{O}_{2}$ and $66 \%$ $\mathrm{N}_{2} \mathrm{O}$. Rectal temperature was monitored continuously and maintained at $37 \pm 0.5^{\circ} \mathrm{C}$ by external heating. For continuous monitoring of arterial blood pressure and blood gases, the left femoral artery was cannulated with polyethylene tubing in subgroup of mice. For laser Doppler measurements, the probe (P403; Perimed, Järfälla, Sweden) was placed $3 \mathrm{~mm}$ lateral and $6 \mathrm{~mm}$ posterior to the bregma. Relative perfusion units were obtained (Periflux 4001; Perimed, Järfälla, Sweden). The left carotid region was exposed through a midline skin incision. A 5-0 nylon filament (Ethilon, Norderstedt, Germany) with a blunted tip was inserted into the common carotid artery and advanced into the internal carotid until the laser Doppler signal decreased considerably. After $15 \mathrm{~min}$ of occlusion, the filament was removed. After $3 \mathrm{~h}$ up to $24 \mathrm{~h}$ of reperfusion, mice were deeply anesthetized with Rompun ${ }^{\mathrm{TM}} /$ Ketanest $^{\mathrm{TM}}$ and perfused with saline (Ringer) or 4\% paraformaldehyde (PFA) in phosphate-buffered saline (PBS). All animal experiments were performed and approved in accordance with the German law.

\section{Monitoring of neurological status}

At day 1 (24 h after MCAO), all surviving animals were examined neurologically using an established scoring system first introduced by Bederson et al. (1986). Contralateral motor deficits of the upper limp were considered as an effect of MCAO.

\section{Mortality}

Mortality was defined as animals that died up to 24 $\mathrm{h}$ after transient MCA occlusion. The animals that died during surgery (bleeding, problems due to anesthesia) were excluded from data analysis.

\section{Assessment of infarct volume}

Twenty four hours after the onset of MCAO mice were perfused, the brains were removed and immediately frozen on dry ice. Coronal cryosections $(20 \mu \mathrm{m})$ were cut at $400 \mu \mathrm{m}$ intervals, starting rostrally. Sections were stained with a silver staining technique, which was shown to be equivalent to other common staining techniques for detecting infarcted tissue (Vogel et al., 1999). Stained sections were directly scanned at $600 \mathrm{dpi}$ and the infarct area was measured (Scion Image, USA). The total infarct volume was obtained by 
A

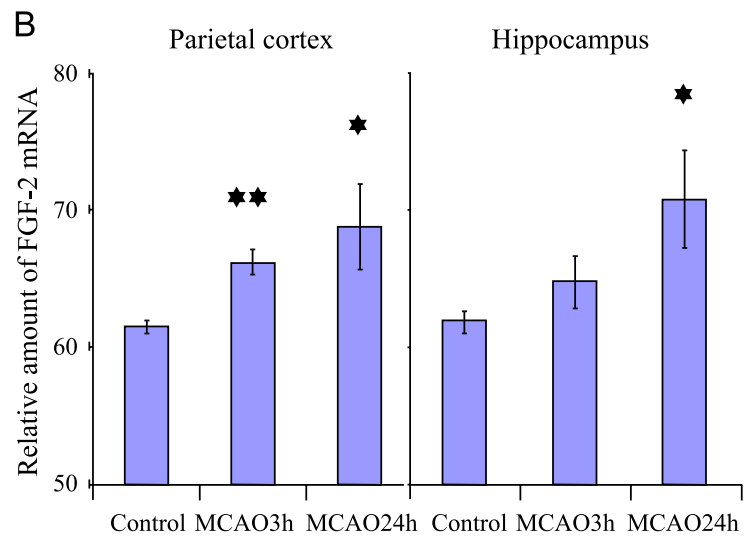

Fig. 1. Increased FGF-2 expression in parietal cortex and hippocampus following MCAO in wild type (FGF-2 (+/+)) mice. (A) Qualitative PCR determination of FGF-2 mRNA in the ipsilateral hippocampal formation and parietal cortex at $3 \mathrm{~h}$ following MCAO or sham surgery, respectively. Representative data are shown. Note the increase in FGF-2 mRNA in response to MCAO. The size of the FGF-2 amplicon is 455 bp, $\beta$-actin amplicon-182 bp. (B) Quantification of FGF-2 mRNA in parietal cortex and hippocampal formation at 3 and $24 \mathrm{~h}$ after MCAO by real-time PCR. Values are expressed relative to cyclophilin mRNA. Values are the means \pm SEM of 4 per group determined in triplicate. $* P<0.05, * * P<0.01$.

integrating infarcted areas and correcting for brain edema (Swanson et al., 1990). Mice without infarct were excluded from the analysis, as this correlated with a low laser Doppler drop during ischemia (more than $25 \%$ of perfusion retained) and was probably due to an inadequate position of the nylon filament. Although a 24-h observation period has been shown in an animal model to be sufficient for full infarct maturation (Connolly et al., 1996), we also monitored animals after $48 \mathrm{~h}$ ischemia. Since only wild types were observed longer as 1 day after ischemia, these observations were not included in the study.

\section{In situ hybridization}

Mice were perfused with 4\% PFA. Brains were removed from the skull and frozen on dry ice. Cryosections $(12 \mu \mathrm{m})$ were cut on a cryostat and mounted on Superfrost slides.
Non-radioactive in situ hybridization (ISH) was carried out as described by Ernsberger et al. (1997). Dig-labeled riboprobes were synthesized from cDNA fragments for murine BDNF (646 bp) and trkB (740 bp) generated by PCR from mouse brain cDNA. The plasmid was appropriately linearized and transcribed with Sp6 and T7 for antisense probe and sense control, respectively. The structures of the BDNF and trkB cDNA probes were as follows: BDNF antisense probe-CTTATGAATCGCCAGCCAAT, BDNF sense control-GCGCCCATGAAAGAAGTAAA; trkB antisense probe-TACCCATCCAGTGGGATCTTA, trkB sense control-TGGCTGAAGTGGCATGGA.

For the quantification of ISH, images were made using a software-controlled (Axiovision 3.0; Zeiss, Germany) digital camera (Axiocam, Zeiss) attached to a microscope (Axioplan imaging; Zeiss). For all images, the same parameters were used (e.g., illumination time, threshold). Images
A

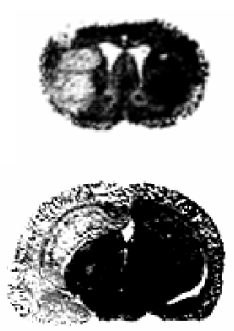

WT
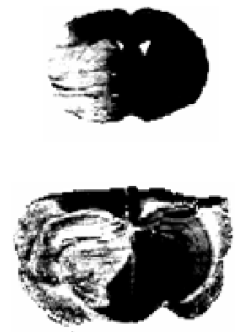

FGF2 KO
B

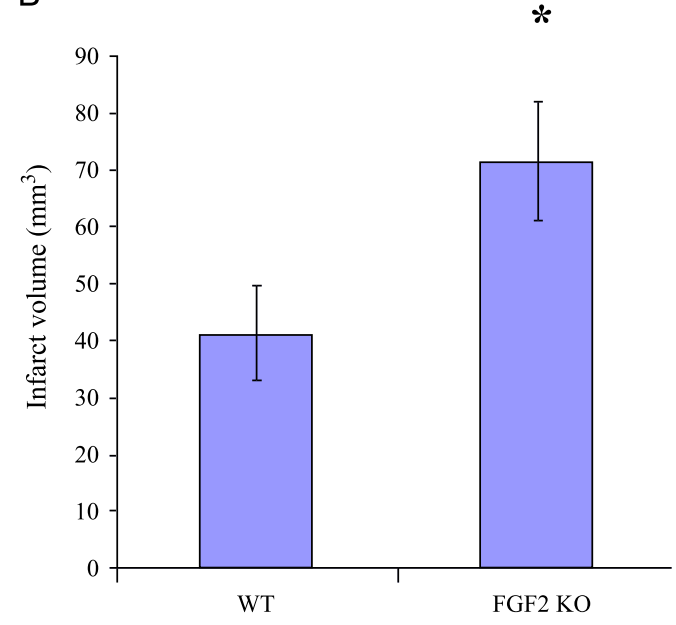

Fig. 2. Infarct volume and histology. (A) Histology of coronal silver-stained sections from brains of an FGF-2 (+/+), (wild type, wt), and an FGF-2 (-/-) (FGF2 KO) mouse after $24 \mathrm{~h}$ of ischemia. White areas indicate ischemic tissue. (B) Quantification of infarct volumes of the ipsilateral hemispheres in mm ${ }^{3}$ were made from 10 animals in each group. Values are given as the mean \pm SEM and compared by unpaired two-tailed $t$ test. $* P<0.05$. 
Table 1

Mortality and neurological deficit after focal ischemia

\begin{tabular}{llr}
\hline Genotype & Mortality & \multicolumn{1}{c}{ Neuroscore } \\
\hline WT (FGF2+/+) & $20.6 \%(6 / 29)$ & $2.1 \pm 0.33(n=10)$ \\
KO (FGF2-/-) & $46.8 \%(15 / 32)^{*}$ & $2.43 \pm 0.42(n=10)$ \\
\hline
\end{tabular}

Mortality. Each value represents percent mortality (number of animals that died up to $24 \mathrm{~h}$ after transient MCA occlusion/number of operated animals) of each genotype. For calculating mortality all animals undergoing MCAO were counted, except animals with inadequate Laser Doppler exponent and animals that died during surgery.

Neuroscore. Values are given in relative units according to Bederson et al. (1986).

* $P<0.05$, Chi-square one-tailed test, compared to wt group.

were stored onto hard disk and analyzed off-line. Intensity measurements were done using ImageJ (NIH, USA). The color-images were changed to 8-bit grayscale images that were represented using unsigned integers in the range $0-$ 255 (256 different gray values, coding for intensities). In each converted image, histograms of the distribution of pixel intensities were made. The mean intensity values were calculated for a specific region of interest (for further details, see also von Bohlen und Halbach et al., 2002), which was defined to cover the area of either the pyramidal layer of the hippocampus, or in the case of the dentate gyrus, the granular layer, as described earlier).

\section{$R T-P C R$}

The ipsilateral hippocampal formation and parietal cortex were prepared from Ringer-perfused brains and immediately frozen on dry ice. Tissues were homogenized under liquid nitrogen and RNA was extracted with Tri-Fast (Invitrogen, Germany). Synthesis of cDNA was done with $1 \mu \mathrm{g}$ of total RNA, M-MLV-RT (Promega, Heidelberg, Germany) and oligo-dT ${ }_{18}$ (New England Labs, Frankfurt, Germany). For qualitative PCR equal amounts of cDNA were used in a set of PCR reactions with a set of primers to amplify $\beta$-actin cDNA (5'-primer: 5'-TCATGAAGTGTGACGTTGACATCCGT-3'; 3'-primer:5' CCTAGAAGCATTTGCGGTGCACGATG- $3^{\prime}$ ) as a house-keeping-gene and a set of primers to amplify FGF-2 cDNA (5'-primer: 5'ATCACCTCGCTTCCCGCA-3' 3'-primer: 5'-TCAGCTCTTAGCAGACATTGG-3'). For quantitative real-time PCR, serial dilutions of cDNA were amplified in parallel with primers for cyclophilin (5'-primer: $5^{\prime}$-ACCCCACCGTGTTCTTCGAC-3'; 3'-primer: 5'-CATTTGCCATGGACAAGATG $-3^{\prime}$ ) as internal standards and FGF-2 (5'-primer: 5'-ATCACCTCGCTTCCCGCA-3' 3'-primer: $5^{\prime}$-TCAGCTCTTAGCAGACATTGG-3') with the SYBRGreen-Kit in GeneAmp-Cycler equipped with GeneAmp 5700SDS software (all from PE Biosystems).

\section{Data analysis}

Quantitative data were expressed as the mean \pm standard deviation (SD) or standard error of the mean (SEM) from at least three experiments. ANOVA (Student-Newman-Keuls post hoc test) and Student's $t$ test were used for statistical analysis (Prism 3.0, Graphpad, USA); $P$ values less than 0.05 were considered as being significant. Neurological scores were evaluated by nonparametric statistical procedures. Survival differences between groups were tested using contingency analysis with the chi-square statistics.

\section{Results}

\section{FGF-2 mRNA is increased following MCAO}

Using RT-PCR increased FGF-2 mRNA accumulation was found in parietal cortex and hippocampus of normal mice (FGF-2 (+/+)) ipsilaterally to the MCA occlusion after $3 \mathrm{~h}$ of reperfusion compared to sham-operated animals (Fig. 1A). At $24 \mathrm{~h}$, there was a significant further increase in FGF-2 mRNA in both areas (Fig. 1B). Together, these data suggest a progressive upregulation in FGF-2 mRNA accumulation during the initial $24 \mathrm{~h}$ following reperfusion. This is consistent with previous reports that have described a significant upregulation of FGF-2 after ischemia using ISH and Northern blot analysis (cf. Lin et al., 1997; Takami et al., 1992).

\section{Infarct volume is enlarged in mice lacking $F G F-2$}

Twenty-four hours after reperfusion, the total infarction volume was assessed by volumetric analysis using silver staining. Fig. 2 shows that total infarct volume was increased by $75 \%$ in FGF-2 (-/-) mice compared to wild type littermates $\left(71.6+10.3 \mathrm{~mm}^{3}\right.$ compared to $41.3+8.3$ $\mathrm{mm}^{3}, P<0.05$.). Increased sensitivity of FGF-2 null mice to ischemic brain injury was accompanied by a significant

Table 2

Physiological conditions in FGF-2 (+/+) and FGF-2 (-/-) mice $24 \mathrm{~h}$ after MCAO

\begin{tabular}{lllcll}
\hline MCAO & $\begin{array}{l}\mathrm{MABP} \\
(\mathrm{mm} \mathrm{Hg})\end{array}$ & $\begin{array}{l}p \mathrm{CO}_{2} \\
(\mathrm{~mm} \mathrm{Hg})\end{array}$ & $\begin{array}{l}p \mathrm{O}_{2} \\
(\mathrm{~mm} \mathrm{Hg})\end{array}$ & $\mathrm{pH}$ & $\begin{array}{l}\mathrm{BG} \\
(\mathrm{mg} / \mathrm{dt})\end{array}$ \\
\hline$F G F-2(+/+)(n=5)$ & & & & \\
Before & $89 \pm 5$ & $39 \pm 6$ & $113 \pm 11$ & $7.34 \pm 0.06$ & $145.5 \pm 9.5$ \\
During & $87 \pm 4$ & $46 \pm 5$ & $92 \pm 13$ & $7.33 \pm 0.04$ & $217.1 \pm 43.8$ \\
After & $93 \pm 4$ & $43 \pm 3$ & $120 \pm 6$ & $7.35 \pm 0.05$ & $167.0 \pm 10.1$ \\
& & & & \\
$F G F-2(-/-)(n=5)$ & & & & \\
Before & $81 \pm 6$ & $41 \pm 4$ & $94 \pm 15$ & $7.32 \pm 0.05$ & $132.5 \pm 21.9$ \\
During & $89 \pm 4$ & $49 \pm 4$ & $110 \pm 14$ & $7.29 \pm 0.07$ & $178.2 \pm 32.5$ \\
After & $97 \pm 6$ & $45 \pm 3$ & $114 \pm 11$ & $7.33 \pm 0.05$ & $161.5 \pm 48.8$ \\
\hline
\end{tabular}

Mice were subjected to transient MCAO followed by reperfusion. Physiological parameters presented here were measured "before" (prior to MCAO), "during" (7 $\mathrm{min}$ after MCAO), or "after" (20 $\mathrm{min}$ of reperfusion) MCAO. Values are means $\pm \mathrm{SD}$. $n$, number of animals. MABP, mean arterial blood pressure; BG, blood glucose. Differences of physiological parameters between groups were not statistically significant ( $P>0.05$, unpaired $t$ test). There were no differences in body temperature values either (data not shown). 

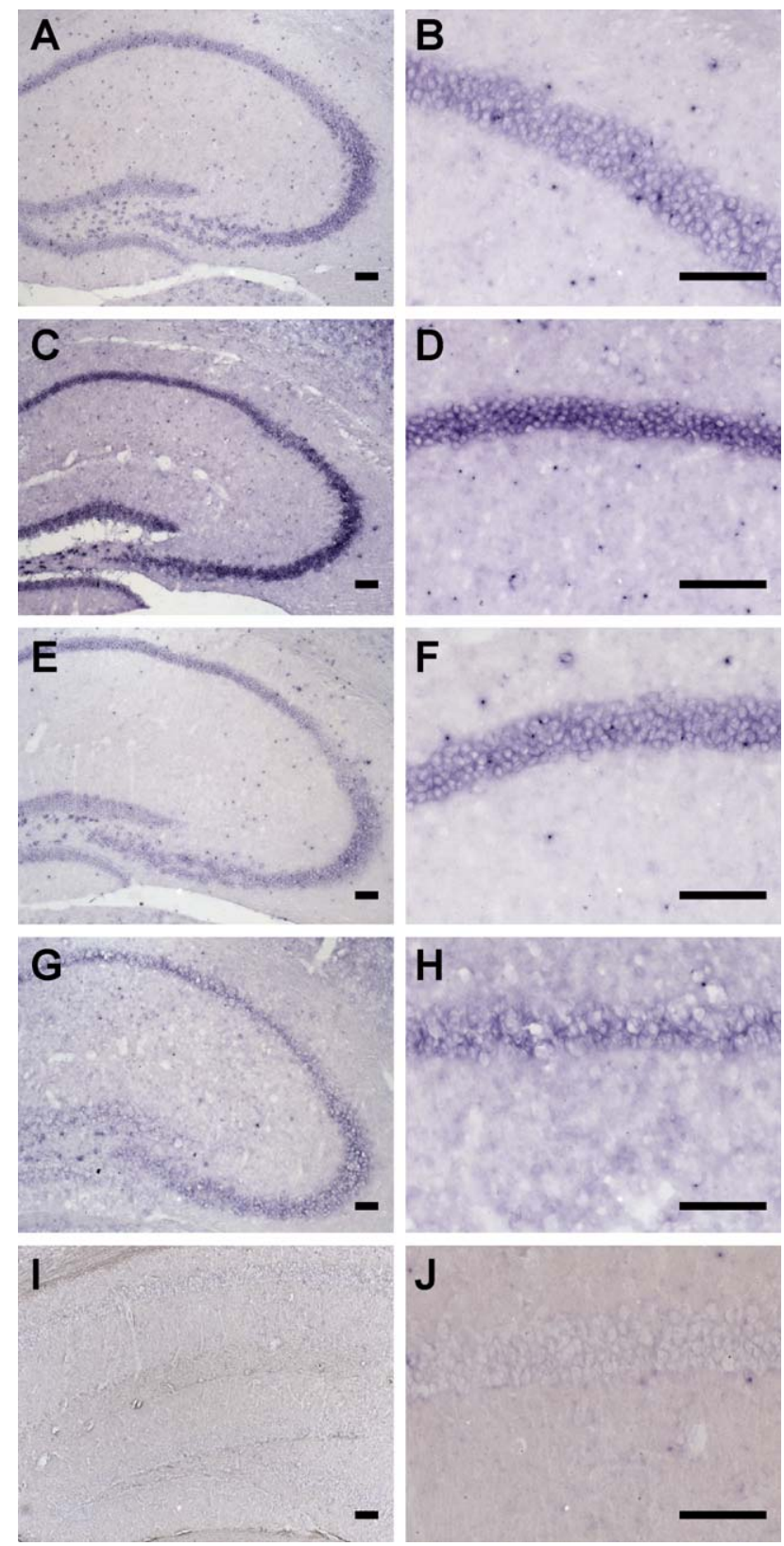

Fig. 3. BDNF mRNA in situ hybridization in the hippocampus (A, C, E, $\mathrm{G}, \mathrm{I})$ and CA1 region (B, D, F, H, J): A, B: FGF-2 (+/+) unlesioned, C, D: FGF-2 (+/+), MCAO E, F: FGF-2 (-/-) unlesioned, G, H: FGF-2 (-/-), MCAO I-J: BDNF sense-controls. Scale bars $=100 \mu \mathrm{m}$.

increase in mortality at $24 \mathrm{~h}$ (Table 1). However, there was no difference in the neurological score between groups (Table 1).

Table 2 provides evidence that physiological variables, including mean arterial blood pressure (MABP), $p \mathrm{CO}_{2}, p \mathrm{O}_{2}$, $\mathrm{pH}$, blood glucose (BG), and body temperature (the latter not shown), showed no significant differences comparing FGF-2 (+/+) and FGF-2 (-/-) mice. Along the same line, Laser Doppler flowmetry provided evidence that CBF reductions in the ischemic core were not significantly different in FGF2 (-/-) compared to wild type mice.
(CBF after $\mathrm{MCAO}$, percent of baseline: $\mathrm{wt},-9.0+2.6 \%$; FGF-2 null mutant, $-8.5+1.7 \% ; P>0.05, t$ test; $n=10$ per group).

\section{Induction of hippocampal BDNF and trkB $m R N A$ expression} after MCAO is compromised in FGF-2 null mice

Previous studies have suggested that BDNF and trkB are upregulated in the ischemic brain (Arai et al., 1996; Schmidt-Kastner et al., 2001). We therefore investigated whether FGF-2 was required for mediating ischemia-related
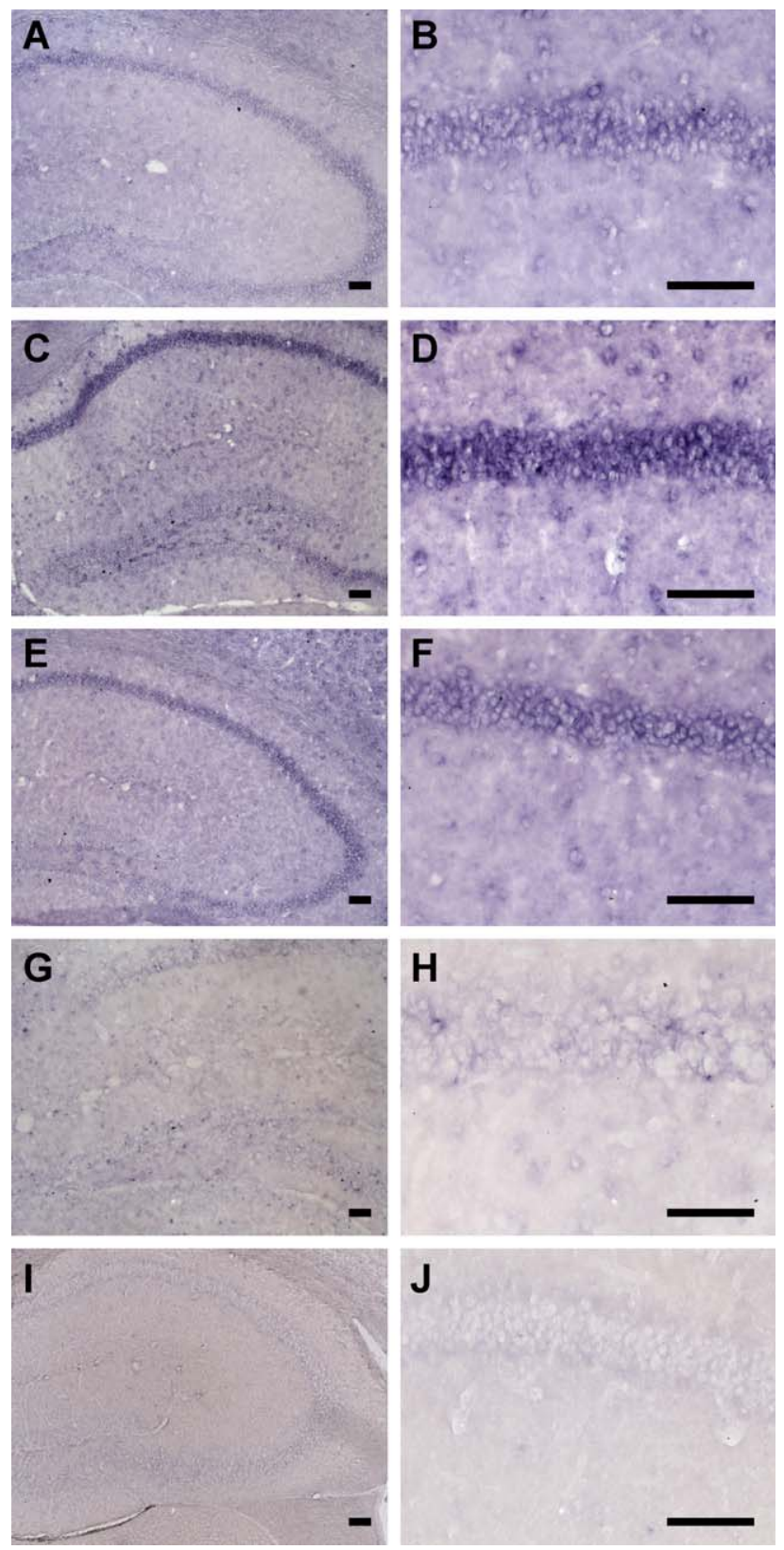

Fig. 4. trkB mRNA in situ hybridization in the hippocampus (A, C, E, G, I) and $\mathrm{CA} 1$ region $(\mathrm{B}, \mathrm{D}, \mathrm{F}, \mathrm{H}, \mathrm{J})$ : A, B: FGF-2 (+/+) unlesioned, C, D: FGF-2 $(+/+)$, MCAO E, F: FGF-2 (-/-) unlesioned, G, H: FGF-2 (-/-), MCAO $\mathrm{I}-\mathrm{J}$ : trkB, sense-controls. Scale bars $=100 \mu \mathrm{m}$. 
BDNF
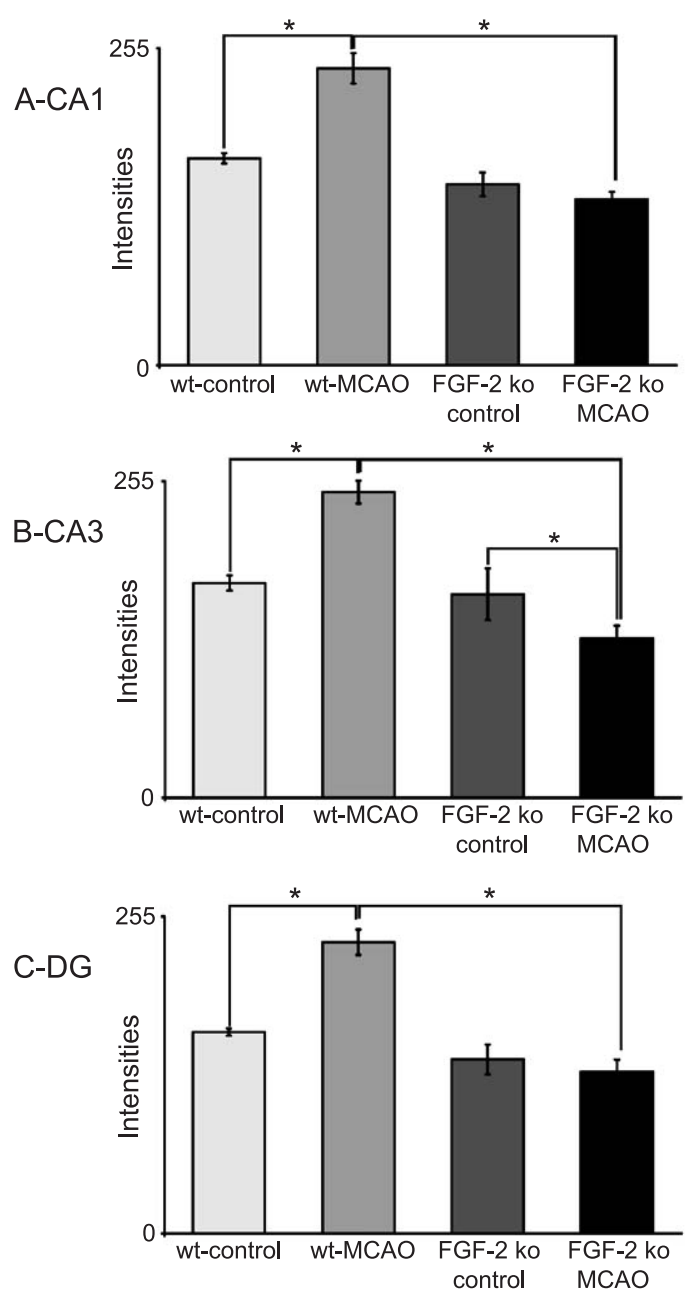

$\operatorname{trkB}$
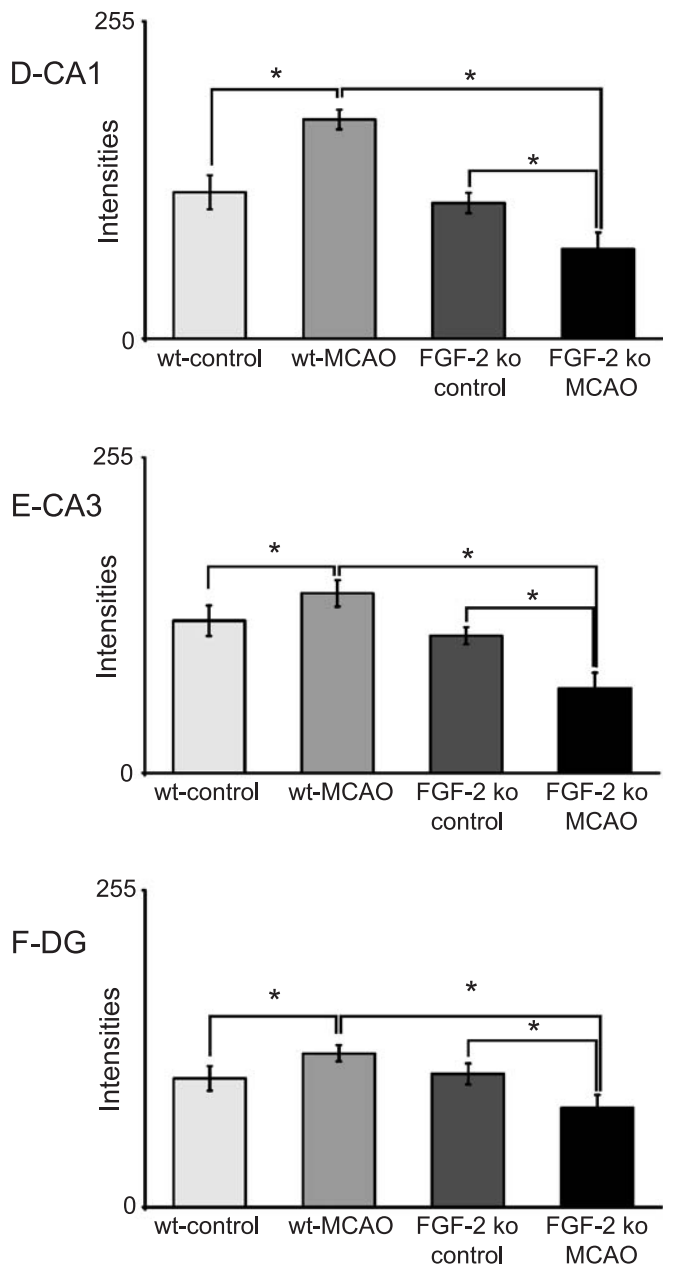

Fig. 5. Quantification (optical density, in situ hybridization) of BDNF mRNA (A-C) and trkB mRNA (D-F) in the hippocampus before and $24 \mathrm{~h}$ after MCAO. Gray scale values are means $\pm \mathrm{SD}$. Determinations were made on three animals per group and experiments were repeated three times. $P<0.01$, ANOVA with Student-Newman-Keuls post hoc test. Abbreviations: CA1 $=$ hippocampal field CA1; CA3 = hippocampal field CA3; DG $=$ dentate gyrus.

induction of BDNF and trkB mRNA using ISH. Figs. 3A and $\mathrm{C}$ show that BDNF mRNA was prominently increased $24 \mathrm{~h}$ after reperfusion in the hippocampal formation of FGF$2(+/+)$ mice. Figs. 3B and D show higher magnifications of the area CA1. In contrast, FGF-2 null mice failed to show such an induction of hippocampal BDNF mRNA (Figs. 3E and $\mathrm{G}$; for higher magnifications of $\mathrm{CA} 1$ area - see Figs. 3F and $\mathrm{H})$. Fig. $4(\mathrm{~A}-\mathrm{H})$ illustrate the trkB expression before $(\mathrm{A}, \mathrm{B})$ and after MCAO $(\mathrm{C}, \mathrm{D})$ in FGF-2 (+/+) and FGF-2 $(-/-)$ mice $(\mathrm{E}-\mathrm{H})$. In situ hybridizations for BDNF mRNA and for trkB mRNA, using sense control probes, are shown in Figs. 3I, J and Figs. 4I, J, respectively.

Quantitative evaluation of optical densities (Figs. 5A-C) revealed a significant $50 \%$ increase in BDNF mRNA in the dentate gyrus and pyramidal layer of the hippocampus in FGF-2 (+/+) mice. This increase was abolished in FGF-2 null mice. Figs. 5D-F demonstrate that trkB mRNA was also upregulated in FGF-2 (+/+). In FGF-2 (-/ ) mice, trkB mRNA was reduced in response to ischemia. Together, these results indicate that lack of FGF-2 compromises the ischemia-mediated upregulation of mRNAs encoding BDNF and its cognate receptor trkB.

\section{Discussion}

Basic fibroblast growth factor (bFGF/FGF-2; Abraham et al., 1986) is a multifunctional growth factor addressing many different cell types. FGF-2 participates, alone or in synergy with other factors, in the control of the proliferation of neuronal progenitor cells (Vescovi et al., 1993), neuronal differentiation (Birren and Anderson, 1990) and survival (Schmidt and Kater, 1995; Unsicker et al., 1987), ion channel expression (Shitaka et al., 1996), neurite outgrowth (Williams et al., 1994), and repair response after injury (Gomez-Pinilla et al., 1992). FGF-2 has been shown to be upregulated not only in ischemic brain tissue (Reilly and Kumari, 1996; Takami et al., 1993; Wei et al., 2000), but 
also after other types of CNS injury including kainateinduced seizures (Bugra et al., 1994) and fimbria-fornix transection (Gomez-Pinilla and Cotman, 1992).

In the present study, we provide the first evidence for a prominent role of endogenous FGF-2 in coping with ischemic brain injury using FGF-2 (-/-) mice subjected to MCAO. While there were no significant differences in ischemia-evoked alterations of several important physiological parameters, including CBF, blood gases, and blood glucose, both infarct volume and mortality were markedly increased in FGF-2 (-/-) mice compared to wild-type littermates. We observed a slight yet not significant decrease in blood pressure in our FGF-2 (-/-) mice suggesting that a difference in vascular tone may not contribute to the differential outcome of ischemia in FGF-2 $(+/+)$ and FGF$2(-/-)$ mice.

Several mechanisms have been proposed to explain the beneficial effects of FGF-2 in brain ischemia. Among these mechanisms are (i) suppression of glutamate-induced elevation of intracellular calcium concentrations and free radical formation, (ii) downregulation of expression of the NMDA receptor-glutamate-binding subunit (Mattson et al., 1993), (iii) induction of the glial cell line-derived neurotrophic factor (GDNF) receptor GFR $\beta 1$ and implication of GDNF in its neurotrophic role (Lenhard et al., 2002).

The present study, by showing a loss of induction of BDNF and trkB mRNAs in FGF-2 null mice, proposes one additional mechanism, by which FGF-2 might exert its neuroprotective potential in brain ischemia, that is, through an induction of BDNF and its receptor trkB. Although FGF-2 has previously been shown to induce several neurotrophic factors, including NGF (Yoshida and Gage, 1991) and GDNF (Suter-Crazzolara and Unsicker, 1996), an inductive role of FGF-2 for BDNF has not been reported as yet. BDNF is essential for development and survival of several distinct neuron populations in vitro and also in vivo, as shown by analyzing BDNF and trkB knockout mice (Boyd and Gordon, 2001; Linnarsson et al., 2000; see Conover and Yancopoulos, 1997, for review). Moreover, beyond its classic trophic role, BDNF plays an important role in the regulation of synaptic plasticity (Kafitz et al., 1999; Korte et al., 1995). In the context of its potential to ameliorate, the consequences of cerebral ischemia (Beck et al., 1994; Schäbitz et al., 1997; $\mathrm{Wu}$ and Pardridge, 1999), both types of mechanisms could be conceived to become effective. Specifically, BDNF has also been shown to improve LTP and cognitive functions after transient forebrain ischemia (Kiprianova et al., 1999). While a causative relationship linking the neuroprotective effect of FGF-2 in cerebral ischemia to the induction of BDNF is conceivable, the existence of two correlative, functionally unlinked phenomena cannot be excluded. Moreover, even the FGF-2-BDNF link does not exclude that lack of activation of other mechanisms attributed to FGF-2 may account for the worsened outcome of cerebral ischemia in FGF-2 null mice.
The main source of FGF-2 in the brain are astrocytes (for review, see Reuss and von Bohlen und Halbach, 2003). It is conceivable that FGF-2 ameliorating the outcome of ischemia directly signals from astroglial cells to adjacent neurons activating FGF receptor-1 (FGFR1), the most prominent FGFR on neurons (Yazaki et al., 1994). Damage of the astroglial cell membrane due to the ischemic insult might facilitate the release of FGF-2, which lacks a conventional signal peptide and whose mode of release from cells has not been clarified as yet. Alternatively, an indirect beneficial role of FGF-2 is also conceivable, for example, by activating other mechanisms leading to neuronal survival.

In conclusion, our results support a prominent neuroprotective role of endogenous FGF-2 in ischemic brain injury. The loss of induction of BDNF and trkB mRNA in ischemic FGF-2 null mice suggests that further exploration of a trophic cascade implying FGF-2 and BDNF may yield novel insights into the trophic signaling networks of the CNS.

\section{References}

Abraham, J.A., Whang, J.L., Tumolo, A., Mergia, A., Friedman, J., Gospodarowicz, D., Fiddes, J.C., 1986. Human basic fibroblast growth factor: nucleotide sequence and genomic organization. EMBO J. 5, 2523-2528.

Arai, S., Kinouchi, H., Akabane, A., Owada, Y., Kamii, H., Kawase, M., Yoshimoto, T., 1996. Induction of brain-derived neurotrophic factor (BDNF) and the receptor trkB mRNA following middle cerebral artery occlusion in rat. Neurosci. Lett. 211, 57-60.

Beck, T., Lindholm, D., Castren, E., Wree, A., 1994. Brain-derived neurotrophic factor protects against ischemic cell damage in rat hippocampus. J. Cereb. Blood Flow Metab. 14, 689-692.

Bederson, J.B., Pitts, L.H., Tsuji, M., Nishimura, M.C., Davis, R.L., Bartkowski, H., 1986. Rat middle cerebral artery occlusion: evaluation of the model and development of a neurologic examination. Stroke 17, 472-476.

Birren, S.J., Anderson, D.J., 1990. A v-myc-immortalized sympathoadrenal progenitor cell line in which neuronal differentiation is initiated by FGF but not NGF. Neuron 4, 189-201.

Boyd, J.G., Gordon, T., 2001. The neurotrophin receptors, trkB and p75, differentially regulate motor axonal regeneration. J. Neurobiol. 49, $314-325$.

Brumwell, C.L., Hossain, W.A., Morest, D.K., Bernd, P., 2000. Role for basic fibroblast growth factor (FGF-2) in tyrosine kinase (TrkB) expression in the early development and innervation of the auditory receptor: in vitro and in situ studies. Exp. Neurol. 162, 121-145.

Bugra, K., Pollard, H., Charton, G., Moreau, J., Ben-Ari, Y., Khrestchatisky, M., 1994. aFGF, bFGF and flg mRNAs show distinct patterns of induction in the hippocampus following kainate-induced seizures. Eur. J. Neurosci. 6, 58-66.

Connolly Jr., E.S., Winfree, C.J., Stern, D.M., Solomon, R.A., Pinsky, D.J. 1996. Procedural and strain-related variables significantly affect outcome in a murine model of focal cerebral ischemia. Neurosurgery 38 , $523-531$.

Conover, J.C., Yancopoulos, G.D., 1997. Neurotrophin regulation of the developing nervous system: analyses of knockout mice. Rev. Neurosci. $8,13-27$.

Dono, R., Texido, G., Dussel, R., Ehmke, H., Zeller, R., 1998. Impaired cerebral cortex development and blood pressure regulation in FGF-2deficient mice. EMBO J. 17, 4213-4225. 
Ernsberger, U., Patzke, H., Rohrer, H., 1997. The developmental expression of choline acetyltransferase (ChAT) and the neuropeptide VIP in chick sympathetic neurons: evidence for different regulatory events in cholinergic differentiation. Mech. Dev. 68, 115-126.

Fisher, M., Meadows, M.E., Do, T., Weise, J., Trubetskoy, V., Charette, M., Finklestein, S.P., 1995. Delayed treatment with intravenous basic fibroblast growth factor reduces infarct size following permanent focal cerebral ischemia in rats. J. Cereb. Blood Flow Metab. 15, 953-959.

Gacek, R.R., Khetarpal, U., Schoonmaker, J., 1998. Morphological and neurochemical correlates of vestibular compensation. Auris, Nasus, Larynx 25, 193-201.

Gomez-Pinilla, F., Cotman, C.W., 1992. Transient lesion-induced increase of basic fibroblast growth factor and its receptor in layer VIb (subplate cells) of the adult rat cerebral cortex. Neuroscience 49, 771-780.

Gomez-Pinilla, F., Lee, J.W., Cotman, C.W., 1992. Basic FGF in adult rat brain: cellular distribution and response to entorhinal lesion and fimbria-fornix transection. J. Neurosci. 12, 345-355.

Hatten, M.E., Liem, R.K., Shelanski, M.L., Mason, C.A., 1991. Astroglia in CNS injury. Glia 4, 233-243.

Herrmann, O., Tarabin, V., Suzuki, S., Attigah, N., Coserea, I., Schneider, A., Vogel, J., Prinz, S., Schwab, S., Monyer, H., Brombacher, F., Schwaninger, M., 2003. Regulation of body temperature and neuroprotection by endogenous interleukin- 6 in cerebral ischemia. J. Cereb. Blood Flow Metab. 23, 406-415.

Jiang, N., Finklestein, S.P., Do, T., Caday, C.G., Charette, M., Chopp, M., 1996. Delayed intravenous administration of basic fibroblast growth factor (bFGF) reduces infarct volume in a model of focal cerebral ischemia/reperfusion in the rat. J. Neurol. Sci. 139, 173-179.

Kafitz, K.W., Rose, C.R., Thoenen, H., Konnerth, A., 1999. Neurotrophinevoked rapid excitation through TrkB receptors. Nature 401, 918-921.

Kiprianova, I., Sandkuhler, J., Schwab, S., Hoyer, S., Spranger, M., 1999. Brain-derived neurotrophic factor improves long-term potentiation and cognitive functions after transient forebrain ischemia in the rat. Exp. Neurol. 159, 511-519.

Kirchhoff, F., Dringen, R., Giaume, C., 2001. Pathways of neuron-astrocyte interactions and their possible role in neuroprotection. Eur. Arch. Psychiatry Clin. Neurosci. 251, 159-169.

Klein, R., 1994. Role of neurotrophins in mouse neuronal development. FASEB J. 8, 738-744.

Korte, M., Carroll, P., Wolf, E., Brem, G., Thoenen, H., Bonhoeffer, T. 1995. Hippocampal long-term potentiation is impaired in mice lacking brain-derived neurotrophic factor. Proc. Natl. Acad. Sci. U. S. A. 92, $8856-8860$

Lenhard, T., Schober, A., Suter-Crazzolara, C., Unsicker, K., 2002. Fibroblast growth factor-2 requires glial-cell-line-derived neurotrophic factor for exerting its neuroprotective actions on glutamate-lesioned hippocampal neurons. Mol. Cell. Neurosci. 20, 181-197.

Lin, T.N., Te, J., Lee, M., Sun, G.Y., Hsu, C.Y., 1997. Induction of basic fibroblast growth factor (bFGF) expression following focal cerebral ischemia. Mol. Brain Res. 49, 255-265.

Lindvall, O., Ernfors, P., Bengzon, J., Kokaia, Z., Smith, M.L., Siesjo, B.K., Persson, H., 1992. Differential regulation of mRNAs for nerve growth factor, brain-derived neurotrophic factor, and neurotrophin 3 in the adult rat brain following cerebral ischemia and hypoglycemic coma. Proc. Natl. Acad. Sci. U. S. A. 89, 648-652.

Linnarsson, S., Willson, C.A., Ernfors, P., 2000. Cell death in regenerating populations of neurons in BDNF mutant mice. Mol. Brain Res. $75,61-69$.

Malcangio, M., Lessmann, V., 2003. A common thread for pain and memory synapses? Brain-derived neurotrophic factor and trkB receptors. Trends. Pharmacol. Sci. 24, 116-121.

Mattson, M.P., Kumar, K.N., Wang, H., Cheng, B., Michaelis, E.K., 1993. Basic FGF regulates the expression of a functional $71 \mathrm{kDa}$ NMDA receptor protein that mediates calcium influx and neurotoxicity in hippocampal neurons. J. Neurosci. 13, 4575-4588.

Merlio, J.P., Ernfors, P., Kokaia, Z., Middlemas, D.S., Bengzon, J., Kokaia, M., Smith, M.L., Siesjo, B.K., Hunter, T., Lindvall, O., 1993. Increased production of the TrkB protein tyrosine kinase receptor after brain insults. Neuron 10, 151-164.

Morrison, R.S., Sharma, A., de Vellis, J., Bradshaw, R.A., 1986. Basic fibroblast growth factor supports the survival of cerebral cortical neurons in primary culture. Proc. Natl. Acad. Sci. U. S. A. 83, 7537-7541.

Ortega, S., Ittmann, M., Tsang, S.H., Ehrlich, M., Basilico, C., 1998. Neuronal defects and delayed wound healing in mice lacking fibroblast growth factor 2. Proc. Natl. Acad. Sci. U. S. A. 95, 5672-5677.

Reilly, J.F., Kumari, V.G., 1996. Alterations in fibroblast growth factor receptor expression following brain injury. Exp. Neurol. 140, 139-150.

Reuss, B., von Bohlen und Halbach, O., 2003. Fibroblast growth factors and their receptors in the central nervous system. Cell. Tissue Res. 313, $139-157$

Reuss, B., Dono, R., Unsicker, K., 2003. Functions of fibroblast growth factor (FGF)-2 and FGF-5 in astroglial differentiation and blood-brain barrier permeability: evidence from mouse mutants. J. Neurosci. 23, 6404-6412.

Saarelainen, T., Lukkarinen, J.A., Koponen, S., Grohn, O.H., Jolkkonen, J., Koponen, E., Haapasalo, A., Alhonen, L., Wong, G., Koistinaho, J., Kauppinen, R.A., Castren, E., 2000. Transgenic mice overexpressing truncated trkB neurotrophin receptors in neurons show increased susceptibility to cortical injury after focal cerebral ischemia. Mol. Cell. Neurosci. 16, 87-96.

Schäbitz, W.R., Schwab, S., Spranger, M., Hacke, W., 1997. Intraventricular brain-derived neurotrophic factor reduces infarct size after focal cerebral ischemia in rats. J. Cereb. Blood Flow Metab. 17, 500-506.

Schmidt, M.F., Kater, S.B., 1995. Depolarization and laminin independently enable bFGF to promote neuronal survival through different second messenger pathways. Dev. Biol. 168, 235-246.

Schmidt-Kastner, R., Truettner, J., Lin, B., Zhao, W., Saul, I., Busto, R., Ginsberg, M.D., 2001. Transient changes of brain-derived neurotrophic factor (BDNF) mRNA expression in hippocampus during moderate ischemia induced by chronic bilateral common carotid artery occlusions in the rat. Mol. Brain Res. 92, 157-166.

Schneider, A., Martin-Villalba, A., Weih, F., Vogel, J., Wirth, T., Schwaninger, M., 1999. NF-kappaB is activated and promotes cell death in focal cerebral ischemia. Nat. Med. 5, 554-559.

Shitaka, Y., Matsuki, N., Saito, H., Katsuki, H., 1996. Basic fibroblast growth factor increases functional L-type $\mathrm{Ca} 2+$ channels in fetal rat hippocampal neurons: implications for neurite morphogenesis in vitro. J. Neurosci. 16, 6476-6489.

Sugimori, H., Speller, H., Finklestein, S.P., 2001. Intravenous basic fibroblast growth factor produces a persistent reduction in infarct volume following permanent focal ischemia in rats. Neurosci. Lett. 300, 13-16.

Suter-Crazzolara, C., Unsicker, K., 1996. GDNF mRNA levels are induced by FGF-2 in rat C6 glioblastoma cells. Mol. Brain Res. 41, 175-182.

Swanson, R.A., Morton, M.T., Tsao-Wu, G., Savalos, R.A., Davidson, C., Sharp, F.R., 1990. A semiautomated method for measuring brain infarct volume. J. Cereb. Blood Flow Metab. 10, 290-293.

Takami, K., Iwane, M., Kiyota, Y., Miyamoto, M., Tsukuda, R., Shiosaka, S., 1992. Increase of basic fibroblast growth factor immunoreactivity and its mRNA level in rat brain following transient forebrain ischemia. Exp. Brain Res. 90, 1-10.

Takami, K., Kiyota, Y., Iwane, M., Miyamoto, M., Tsukuda, R., Igarashi, K., Shino, A., Wanaka, A., Shiosaka, S., Tohyama, M., 1993. Upregulation of fibroblast growth factor-receptor messenger RNA expression in rat brain following transient forebrain ischemia. Exp. Brain Res. 97, 185-194.

Unsicker, K., Reichert-Preibsch, H., Schmidt, R., Pettmann, B., Labourdette, G., Sensenbrenner, M., 1987. Astroglial and fibroblast growth factors have neurotrophic functions for cultured peripheral and central nervous system neurons. Proc. Natl. Acad. Sci. U. S. A. 84, 5459-5463.

Vescovi, A.L., Reynolds, B.A., Fraser, D.D., Weiss, S., 1993. bFGF regulates the proliferative fate of unipotent (neuronal) and bipotent (neuronal/astroglial) EGF-generated CNS progenitor cells. Neuron $11,951-966$. 
Vogel, J., Mobius, C., Kuschinsky, W., 1999. Early delineation of ischemic tissue in rat brain cryosections by high-contrast staining. Stroke 30, $1134-1141$.

von Bohlen und Halbach, O., Albrecht, D., Heinemann, U., Schuchmann, S., 2002. Spatial nitric oxide imaging using 1,2-diaminoanthraquinone to investigate the involvement of nitric oxide in long-term potentiation in rat brain slices. Neuroimage 15, 633-639.

Walicke, P., Cowan, W.M., Ueno, N., Baird, A., Guillemin, R., 1986. Fibroblast growth factor promotes survival of dissociated hippocampal neurons and enhances neurite extension. Proc. Natl. Acad. Sci. U. S. A. 83, 3012-3016.

Wei, O.Y., Huang, Y.L., Da, C.D., Cheng, J.S., 2000. Alteration of basic fibroblast growth factor expression in rat during cerebral ischemia. Acta Pharmacol. Sin. 21, 296-300.

Williams, E.J., Furness, J., Walsh, F.S., Doherty, P., 1994. Characterisation of the second messenger pathway underlying neurite outgrowth stimulated by FGF. Development 120, 1685-1693.

Wu, D., Pardridge, W.M., 1999. Neuroprotection with noninvasive neu- rotrophin delivery to the brain. Proc. Natl. Acad. Sci. U. S. A. 96, $254-259$.

Yazaki, N., Hosoi, Y., Kawabata, K., Miyake, A., Minami, M., Satoh, M., Ohta, M., Kawasaki, T., Itoh, N., 1994. Differential expression patterns of mRNAs for members of the fibroblast growth factor receptor family, FGFR-1-FGFR-4, in rat brain. J. Neurosci. Res. 37, 445-452.

Yoshida, K., Gage, F.H., 1991. Fibroblast growth factors stimulate nerve growth factor synthesis and secretion by astrocytes. Brain Res. 538, $118-126$.

Yoshimura, S., Teramoto, T., Whalen, M.J., Irizarry, M.C., Takagi, Y., Qiu, J., Harada, J., Waeber, C., Breakefield, X.O., Moskowitz, M.A., 2003. FGF-2 regulates neurogenesis and degeneration in the dentate gyrus after traumatic brain injury in mice. J. Clin. Invest. 112, 1202-1210.

Zhou, M., Sutliff, R.L., Paul, R.J., Lorenz, J.N., Hoying, J.B., Haudenschild, C.C., Yin, M., Coffin, J.D., Kong, L., Kranias, E.G., Luo, W., Boivin, G.P., Duffy, J.J., Pawlowski, S.A., Doetschman, T., 1998. Fibroblast growth factor 2 control of vascular tone. Nat. Med. 4, $201-207$. 